УДК 334.722.24:339.944

Солоненко Ю. В., старший викладач кафедри підприємництва, корпоративної та просторової економіки Донецького національного університету імені Василя Стуса

\title{
ІНТЕРНАЦІОНАЛІЗАЦІЯ СІМЕЙНОГО БІЗНЕСУ: СУТНІСТЬ ПРОЦЕСУ ТА ЧИННИКИ ВПЛИВУ
}

У статті розглянуто роль та місце сімейного бізнесу як ефективної форми підприємництва у світовій економіці. Представлено інтернаціоналізацію сімейних компаній як тенденцію сучасного підприємницького середовища. Визначено зміст та напрями інтернаціоналізації сімейного бізнесу. Узагальнено чинники впливу та особливості інтернаціоналізації сімейних компаній. Приведено приклади інтегрування українських сімейних компаній у світову економіку. Виявлено переваги інтернаціоналізації для сімейних компаній. Окреслено взаємозв'язки між інтернаціоналізацією і брендами сімейного бізнесу, управлінням сімейними фірмами, комунікаційною мережею сімейних компаній. Запропоновано перспективні маркери подальших досліджень, серед яких: вплив інтернаціоналізації сімейних компаній на розвиток сімейного бізнесу на внутрішньому ринку; брендинг та інтернаціоналізація; професіоналізація сімейних менеджерів і інтернаціоналізація; навчання за кордоном i інтернаціоналізація власного сімейного бізнесу; роль несімейних менеджерів в інтернаціоналізації сімейного бізнесу.

Ключові слова: сімейний бізнес, тенденції сімейного бізнесу, інтернаціоналізація сімейного бізнесу, брендинг сімейного бізнесу, професійність сімейного бізнесу, мережа сімейного бізнесу

Рис. 1, Літ. 10

\section{Солоненко Ю. В.}

\section{ИНТЕРНАЦИОНАЛИЗАЦИЯ СЕМЕЙНОГО БИЗНЕСА: СУЩНОСТЬ ПРОЦЕССА И ФАКТОРЫ ВЛИЯНИЯ}

В статье рассмотрена роль и место семейного бизнеса как эффективной формы предпринимательства в мировой экономике. Представлена интернационализация семейных компаний как тенденция современной предпринимательской среды. Определено содержание и направления интернационализации семейного бизнеса. Выявлены факторы влияния и особенности интернационализации семейных компаний. Приведены примеры интеграции украинских семейных компаний в мировую экономику. Определены преимущества интернационализации для семейных компаний. Очерчены взаимосвязи между интернационализацией и брендами семейного бизнеса, управлением семейныи фирмами, коммуникационной сетью семейных компаний. Предложены перспективные маркеры дальнейших исследований, среди которых: влияние интернационализации семейных компаний на развитие семейного бизнеса на внутреннем рынке; брендинг и интернационализация; профессионализация семейных менеджеров и интернационализация; обучение за рубежом и интернационализация собственного семейного бизнеса; роль несемейных менеджеров в интернационализации семейного бизнеса.

Ключевые слова: семейный бизнес, тенденции семейного бизнеса, интернационализация семейного бизнеса, брендинг семейного бизнеса, профессионализм семейного бизнеса, сеть семейного бизнеса 


\section{Solonenko Yu. INTERNATIONALIZATION OF FAMILY BUSINESS: THE ESSENCE OF THE PROCESS AND THE FACTORS OF INFLUENCE}

The article examines the role and place of the family business as an effective form of entrepreneurship in the world economy. The internationalization of family companies as a trend of the modern entrepreneurial environment is presented. The content and directions of the internationalization of the family business are defined. Factors of influence and peculiarities of internationalization of family companies are revealed. Examples of the integration of Ukrainian family companies into the world economy are given. The advantages of internationalization for family companies are determined. The interrelations between internationalization and brands of family business, management of family firms, and the network of family companies are outlined. Promising markers for further research are proposed, among which: the impact of the internationalization of family companies on the development of family business in the domestic market; branding and internationalization; professionalization of family managers and internationalization; training abroad and internationalization of their own family business; The role of non-family managers in the internationalization of the family business.

Key words: family business, family business trends, internationalization of family business, family business branding, professionalism of family business, family business network.

Постановка проблеми. На сучасному етапі розвитку світової економіки сімейний бізнес продовжує залишатись найпоширенішою та найефективнішою формою господарювання. Сімейний бізнес номінально присутній у кожному куточку світу. Часто сімейні фірми колективно домінують як в економіці конкретної країни, так і в окремих регіонах. За визначенням провідних експертів, науковців та існуючого обсягу досліджень, сімейний бізнес визнається як основна і найбільш стійка модель бізнесу в світі $[1,2,3,4,5,6,7]$.

За європейською моделлю, сімейною вважається та фірма, де:

1. Права на прийняття рішень знаходяться в розпорядженні фізичної особи (осіб), які управляють фірмою, або у володінні фізичної особи (осіб), що мали/придбали Статутний капітал фірми, або у володінні подружжя, батьків, дітей.

2. Більшість прав з прийняття рішень можуть бути як непрямими так і прямими.

3. Принаймні, один представник родини або родичів формально бере участь в управлінні фірмою.

4. Список компаній, які підпадають під визначення сімейного підприємства, це коли людина, яка створила або придбала фірму (акціонерний капітал) або члени iii сім'ї чи нащадки мають 25\% директивних прав, внесених до їх Статутного капіталу. (Визначення прийняте групою експертів СC з Family Business) [1].

В Україні, після здобуття незалежності, відбувається лише становлення сімейного бізнесу, тому проблеми формування, механізми функціонування, світові тенденції розвитку мають викликати зацікавлення як у власників компаній, так і у вітчизняних науковців.

Згідно національного дослідження приватного та сімейного бізнесу, яке було проведено в 2013 році, на запитання анкети «Як, на Ваш погляд, держава може підтримати малий і середній приватний бізнес?» лише 7,5\% українських респондентів позитивно відзначили здатність підтримання державою міжнародної експансії приватного бізнесу, мабуть, поки що не розуміючи можливостей, які можуть перед ними відкритися [2]. 
Аналіз останніх досліджень і публікацій свідчить, що питаннями сімейного бізнесу, з позицій тенденцій, нових трендів та закономірностей розвитку займається широке коло зарубіжних вчених та практиків на відміну від українських. До недавнього часу аналіз інтернаціоналізації сімейних фірм був досить маргінальним. Проте тема інтернаціоналізації сімейного бізнесу сформувалось в значну область досліджень, про що зазначали Sciascia, Mazzola, Astrachan та Pieper (2010). Інтернаціоналізацію як фактор, що суттєво впливає на розвиток сімейного бізнесу досліджували Gallo та Sveen (1991), Gallo та Pont (1996), Okoroafo (1999), Davis та Harveston (2000), Yeung (2000), Casillas та Acedo (2005), Férnandez та Nieto (2005), George, Wiklund та Zahra (2005), Menéndez-Requejo (2005), Thomasta Graves (2004, 2008), Casillas (2007). Управлінські стратегічні питання, що стосуються інтернаціоналізації сімейного бізнесу були проаналізовані Svinth та Vinton (1993), Zahra (2003), Thomas та Graves (2005, 2006), Erdner тa Shapiro (2005), Crick, Bradshaw тa Chaundhry (2006), Fernández ta Nieto (2006), Basly (2007), Pinho (2007) та Claver, Rienda та Quer (2008). Процес інтернаціоналізація був у полі наукової уваги таких вчених, як Johanson та Vahlne (1977, 1990), Tsang (2001, 2002), Child, Ng та Wong (2002), Claver, Rienda тa Quer (2007), Thomas тa Graves (2008). Класична література свідчить, що малі та середні фірми опиняються в невигідному становищі порівняно 3 великими корпораціями при вирішенні проблем інтернаціоналізації, про що писали Bonaccorsi (1992), OECD (1997), Nummela (2004).

При роботі над статтею використано такі методи дослідження як аналіз, синтез, порівняння, узагальнення, емпіричне спостереження, застосовано системний підхід.

Мета статті. Виявити та проаналізувати основні тенденції розвитку світового сімейного бізнесу в умовах глобальної ринкової економіки 3 перспективами застосування результатів дослідження в українських реаліях (на прикладі інтернаціоналізації сімейних фірм).

Виклад основного матеріалу дослідження. Сімейний бізнес початку 21 століття, на наш погляд, характеризується такими основними тенденціями розвитку як інтернаціоналізація, професіоналізація, брендинг та розвиток мереж, які тісно взаємодіють, впливаючи одне на одного. Сімейний бізнес, сповідуючи довгострокову перспективу розвитку, намагається якнайдовше залишатись на ринку, застосовуючи набір різноманітних стратегій, які проходять перевірку часом.

На сучасному етапі розвитку відбувається відчутна глобалізація суспільного та економічного життя, сприяючи формуванню цілісного світового господарства на основі розвитку плідних взаємозв'язків між фірмами, країнами й регіонами.

Інтернаціоналізацію (internationalization) сімейного бізнесу ми розглядаємо як процес адаптації продукту чи послуг до соціокультурних особливостей регіону, відмінного від того, в якому вони розроблялись 3 метою раціонального використання та поширення. Інтернаціоналізацію сімейного бізнесу можна було б досліджувати 3 позицій глобалізації наукових досліджень, отримання професійної освіти у визнаних міжнародних бізнес-школах, впливу мережевої структури, ролі міжнародних інститутів, та ми зупинимося на міжнародній діяльності сімейних компаній як таких.

Johanson, J. та Vahlne, J-Е. стверджують, що причинами зарубіжної експансії є: по-перше - вірогідне знаходження нових бізнес-можливостей, по-друге - формування ціннісних партнерських відносин [3, с.14-15].

Нами було виокремлено ще низку ймовірних здобутків для сімейних компаній при реалізації стратегії інтернаціоналізації:

- інтернаціоналізація свідчить про планування довгострокової та неперервної перспективи розвитку, (що характерно для сімейного бізнесу); 
- мотивація до інтернаціоналізації позитивно пов'язана 3 правонаступництвом в наступному поколінні, особливо, коли майбутнє покоління буде знаходитись на керівних посадах у сімейному бізнесі;

- набуття нових знань, умінь, навичок, досвіду;

- формування мережі, зв'язків, прихильностей, довіри;

- репутаційний капітал сімейного бізнесу та Кодекси етики компаній надають особливі можливості для входження на міжнародний ринок;

- брендинг сімейного бізнесу і інтернаціоналізація - взаємопов'язані процеси;

- відбувається постійний процес адаптування до мінливого ринкового середовища;

- здійснюється перевірка на практиці ефективності стратегічного менеджменту компанії для успішної міжнародної експансії;

- можливість знаходження в «іншому» інституційному полі;

- венчурний капітал та інституціональні власники пов'язують інтереси «сімейного» генерального директора та команди топ-менеджерів, заохочуючи до більш масштабних процесів інтернаціоналізації сімейного бізнесу;

- інтернаціоналізація сімейного бізнесу сприяє ефективному функціонуванню сімейних компаній на внутрішньому ринку (характерно для національного сімейного бізнесу, особливо у сфері IT-технологій, творчої індустрії, легкої промисловості, аграрного бізнесу тощо);

- відбувається слідування за сімейними компаніями в процесі інтернаціоналізації клієнтів, партнерів, постачальників, інвесторів.

Інтернаціоналізація - це найбільш складна, але в той же час ефективна стратегія, яку сімейний бізнес може обрати. Складність для невеликих сімейних підприємств полягає у можливостях залучення необхідних фінансових ресурсів, щоб подолати виклики, які неодмінно будуть супроводжувати цей процес. Часто сімейні компанії підтримують себе за рахунок коштів, наданих власниками та їх сім'ями. Це $\epsilon$ непростим завданням для сімейних фірм, щоб накопичити ресурси, необхідні для підтримки конкурентних переваг, які можуть бути використані і на інтернаціоналізацію в тому числі. Thomas J., Graves C. (2008) досліджували основні детермінанти шляхів інтернаціоналізації для малих і середніх сімейних підприємств і яким чином сімейні осередки впливають на ці детермінанти і виявили, що накопичених ресурсів, для підтримки конкурентних переваг, які можуть бути використані на інтернаціоналізацію не завжди вистачає [4].

На основі вибірки з іспанських сімейних фірм підтверджено наявність значущого зв'язку між типом власності та стратегією інтернаціоналізації. Вчені виявили негативний зв'язок між сімейною власністю та експортною інтенсивністю. Сімейним фірмам складніше сформувати портфель стратегічних ресурсів, щоб домогтися успіху на зарубіжних ринках, адже необхідно тримати баланс між сім'єю та бізнесом. Сімейна власність може мати як позитивний, так i негативний вплив на рішення інтернаціоналізації, засновані на агентській чи опікунській перспективі. Механізми моніторингу, створення ієрархічної форми управління і реалізація програми Ради директорів слугують процесам входження на зовнішні ринки.

Управління міжнародною конкурентоспроможністю підприємств передбачає: використання будь-яких стратегічних переваг, котрі пов'язані 3 господарським портфелем компанії, і перетворення їх на конкурентні переваги; оцінювання перспектив рентабельності (продуктивності) для кожного 3 підрозділів підприємства i концентрування корпоративних ресурсів там, де існують найпривабливіші стратегічні можливості та відкриті глобальні ніші. Управлінський потенціал (команда управління), управлінський досвід (використання сторонніх менеджерів, навчання) та здійснення 
управлінських процесів (стратегічне планування, фінансова звітність, загальне управління якістю і забезпечення якості) сімейних підприємств, безумовно, впливають на рівень інтернаціоналізації.

У доповіді OECD (Організація економічного співробітництва і розвитку) стверджується, що процес інтернаціоналізації схоже прискорюється. Процес інтернаціоналізації сімейних підприємств не такий довготривалий тепер, як це було десятиліття тому. Сімейні фірми розпочинають, як правило, процес інтернаціоналізації шляхом експорту, оскільки ії вимоги, ризики та докладені зусилля мінімальні.

Так, як мережі та особисті відносини мають вирішальне значення для інтернаціоналізації, зокрема, у творчій індустрії, то подібні компанії, здається, хочуть зменшити ризики при допомозі посередників, надаючи перевагу використанню продюсер/менеджер порталів, щоби через посередників і менеджерів виходити на світові ринки.

На рис. 1 відображена роль мережі у процесі інтернаціоналізації фірм.

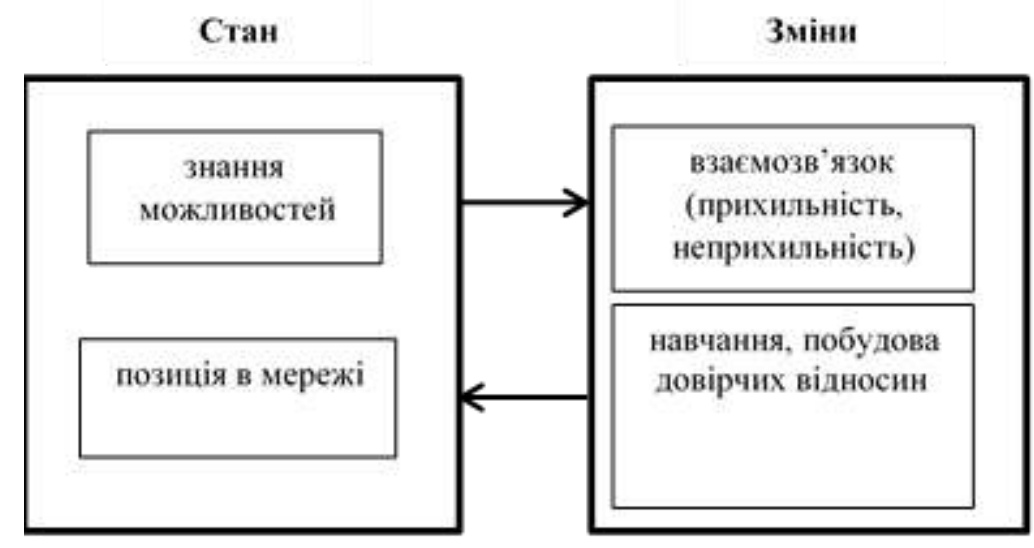

Рис. 1 - Мережева модель бізнес-процесу інтернаціоналізації

*адаптовано автором

Фірма може створювати нові знання при допомозі обміну даними через мережу взаємопов'язаних відносин. Відносини партнерів $є$ непрямим джерелом актуальної ділової інформації про своїх партнерів і більш віддалені суб'єкти у мережі. Інтернаціоналізацію можна розглядати як результат дії по зміцненню позицій в мережі, що традиційно іменується покращенням або захистом становища на ринку. Модель описує процес навчання, а також формування довірчих стосунків. Підвищений рівень знань може мати як позитивний, так і негативний вплив на зміцнення довіри i прихильності. Знання також можуть знижувати прихильність або навіть сприяти розірванню відносин. Ці процеси можуть відбуватись по обидві сторони взаємних відносин і у всіх точках мережі.

Кодекси етики є не стільки новим явищем у сімейному бізнесі, але через поширення глобалізації, компанії почали масово приймати їх для того, щоб переконатися, що вони будуть розглядатись як моральні організації на ринку. Зростаюча глобалізація означає, що багато компаній швидко поширюються на нові ринки в нових країнах, і тому вони вимушені діяти крос-культурно. Працівники фірм зіткнулися 3 етичними дилемами, як результат, виникла підвищена потреба в неформальних правилах та етичних кодах. Коди, насамперед, формують етичні параметри - що прийнятно, а що ні.

«Війна за таланти», тобто підбір кваліфікованих кадрів $є$ ще однією складовою на шляху здійснення міжнародної експансії (інтернаціоналізації), яка в певній мірі обмежена для малого та середнього сімейного бізнесу. 
Відсутність горизонтальної диференціації і формалізації в сімейному бізнесі надають можливості швидко реагувати на зміни, але в той же час серйозно перешкоджають як в національному, так i в міжнародному зростанні. Інтернаціоналізація вимагає створення більш складних структур та здійснення формального контролю.

Багато сімейних компаній стали впізнаваними завдяки своїм брендам. Найбільш популярними світовими брендами сімейного бізнесу є:

Австрія (Red Bull, Swarovski Crystal), Данія (Lego), Франція (Hermes, L'Oreal, Gucci, Puma, Peugeot, Citroen), Німеччина (Adidas, BMW, Bosch, Henkel, Metro, Porsche, Siemens), Італія (Benetton, Ferrero, FIAT, Prada), Японія (Тoyota, Suntory), Південна Корея (Korean Air, LG, Samsung, Hyundai), Південна Африка (De Beers), Нідерланди (Heineken), США (Cargill, Ford Motor, Hallmark, Hilton, Mars, Wal-Mart) та багато інших.

Престиж, досягнутий брендом, часто використовується як парасольковий бренд, так як він поєднується з широким вибором продукції компанії і передає стиль життя та почуття приналежності клієнта до бренду. Бренд стає елементом нематеріальних активів фірми і працює на майбутнє фірми, в даному дослідженні, можна припустити, на інтернаціоналізацію. Сімейний бізнес, особливо той, який успішно переходив від одного покоління до іншого, пройшов випробування часом. Підкреслюючи здатність сім'ї в підтримці бізнесу протягом багатьох років, створюються традиції, спрямовані на сімейні цінності, єдність, гармонію та дотримання якості. 3 іншого боку, це відповідає образу, який відклався у свідомості клієнта і асоціюється з брендом компанії, який включає в себе уявлення про продукт, ідеї, послуги, часто носить ім'я творця фірми.

За даними дослідження, результати опитування респондентів свідчать, що окремий бренд сімейного бізнесу може внести свій вклад в репутацію компанії в надійності (81\%), у соціальній відповідальності (70\%), орієнтації на якість $(68 \%)$ і орієнтації на клієнта (67\% ). Додатково 65\% респондентів повідомили, що вони використовують свою корпоративну репутацію, щоб мати кращі позиції на ринку, в тому числі міжнародному, в порівнянні з їх несімейними конкурентами [5].

Інтернаціоналізація сімейних фірм здійснюється, в основному, через:

- експорт та імпорт товарів та послуг;

- ліцензування і франчайзинг;

- управлінські угоди;

- підряд і субпідряд на виконання робіт;

- створення дочірніх компаній та спільних підприємств;

- у участь в альянсах.

Отже, більшість сімейних компаній розпочинає процес інтернаціоналізації шляхом створення бізнесу на своїх внутрішніх ринках, а вже потім переходять до імпорту чи експорту. Якщо вони стають успішними, то встановлюють канали збуту за кордон, перш ніж перейти на більш просунутий рівень інтернаціоналізації, такий як спільні підприємства або іноземні прямі інвестиції. Тільки невелика частка міжнародноактивних суб'єктів сімейного бізнесу розпочинають свою діяльність безпосередньо 3 міжнародних альянсів.

Одним з основних факторів, що визначають міжнародний успіх $є$ задоволення клієнтських потреб і адаптація продукції або послуг до вимог закордонних замовників. Початкова інтернаціоналізація часто включає регіони, які географічно і культурно близькі, щоб допомогти сімейним фірмам подолати психологічний бар'єр прийняття першого міжнародного кроку, покладаючись на особисті контакти та знайомства, які легше знайти в географічно і культурно близьких регіональних ринках. 
Pinho J-C. (2007) вивчаючи інтеграційні процеси сімейних компаній виявив, що вони мають досить гнучкий характер, і навіть схильні співпрацювати 3 державними структурами, мінімізуючи ризики, пов'язані з іншим інституційним середовищем, та їм необхідно підвищувати свій рівень знань про зарубіжні ринки та діяльність міжнародних компаній [6].

Claver Е. і співавтори (2007) підкреслюють роль державного управління в міжнародній експансії сімейних фірм і закликають вжити заходів у наданні консультацій та навчання з інтернаціоналізації для нових поколінь з метою підвищення значення міжнародного діяльності сімейних фірм [7, с. 12-13].

Український сімейний бізнес вивчає, відображає, інтерпретує та адаптує кращі світові практики інтернаціоналізації сімейного підприємництва.

Зразок міжнародних управлінських угод можна віднайти у структурі вітчизняної компанії RedHead Family Corporation, вищим органом прийняття ключових рішень в якій є Зовнішня рада директорів, куди входять авторитетні лідери з сімейного бізнесу і фінансів у світі. Зовнішня рада директорів створена в 2011 році для забезпечення підзвітності та прозорості дій генерального директора, СЕО. Рада відповідає за призначення СЕО і знаходиться в постійній комунікації з командою топ-менеджерів (Dream Team), що стоять на чолі бізнес-напрямків і департаментів.

Зовнішня Рада директорів RedHead Family Corporation:

Joseph Astrachan, USA, професор менеджменту і підприємництва університету Кеннесо (США), виконавчий директор Центру підприємництва сім'ї Кокс (Сox Family Enterprise Center). Дослідник сімейного бізнесу №1 в світі. Входить в склад ради директорів ще семи сімейних компаній.

Reinout van Lennep, Switzerland, незалежний радник 3 фінансових питань i сімейного управління. Член зовнішньої ради директорів VM Partners (Цюріх). Радник заможних сімей в Швейцарії, США, Великобританії, Східній Європі, Сінгапурі, Аргентині. У минулому - керівник сектору міжнародного приватного банківського обслуговування і генеральний директор банку ABN AMRO (Швейцарія). Працював в керівництві відділень ABN AMRO в Гонконзі, Тайвані, Великобританії. Обіймав посаду віце-президента JP Morgan (Великобританія). Магістр права, закінчив юридичну школу університету Лейдена (Нідерланди).

Vadim Margulis, USA, Президент JGM Group Inc. (США), інвестиційноконсалтингової компанії, яка фокусується на ринках США і Східної Свропи. Експерт $з$ корпоративних фінансів та стратегічного менеджменту, з досвідом роботи в провідних світових інвестиційних та консалтингових компаніях Accenture, McKinsey, Bear Stearns i Equifin Capital. Закінчив Одеський національний університет і Школу економіки i фінансів «Вартон» Пенсільванського університету [8].

Наприклад, сімейна компанія GST (Global Security Technologies), відома як виробник охоронних пломб, співпрацює з 50 країнами світу. Компанія була створена в 1998 році в Одесі. 32003 року розпочала поставки власної виробленої продукції на міжнародний ринок. Торгова марка «Охоронні пломби GST» зареєстрована в місті Женева, Швейцарія. Серед стратегічних завдань: займати 70\% ринку України з продажу охоронних пломб; здійснювати поставки в 150 країн світу; відкрити представництва в 35 країнах [9].

Ще одна українська сімейна компанія Ескада-М, виробник шпонованих плит вже більше 9 років успішно працює на вітчизняному ринку та займається експортом власної продукції у Велику Британію, Данію, Швецію, Швейцарію, Польщу, Білорусь та Молдову, активно впроваджуючи світові стандарти операційної ефективності (KAIZEN, TOC). Серед клієнтів компанії Hyatt Hotels Corporation, Hilton, Coca Cola, Facebook [10]. 
Таким чином, інтеграційні процеси, які відбуваються у світовому господарстві формують умов для інтернаціоналізації сімейного бізнесу, створюючи глобальне конкурентне інституційне середовище, систему соціально-комунікаційних зв'язків, забезпечивши міжнародний розподіл праці.

Висновки. Інтернаціоналізація сімейного бізнесу характеризується певними особливостями: сімейним фірмам не вистачає спланованої стратегії міжнародної експансії; процес інтернаціоналізації прискорюється, становлячи кілька років; інтернаціоналізацію можна розглядати як результат діяльності сімейних фірм по зміцненню позицій в бізнес-мережі; сімейні компанії намагаються працювати в більш привабливому інституційному полі, використовуючи знання та формуючи взаємозв'язки; мережева взаємодія сприяє міжнародному визнанню сімейних компаній, зростанню професіоналізації в сімейному бізнесі, створенню та розвитку брендів.

Перспективи подальших досліджень: вплив інтернаціоналізації сімейних компаній на розвиток сімейного бізнесу на внутрішньому ринку; брендинг та інтернаціоналізація; професіоналізація сімейних менеджерів і інтернаціоналізація; навчання за кордоном і інтернаціоналізація власного сімейного бізнесу; роль несімейних менеджерів в інтернаціоналізації сімейного бізнесу.

\section{СПИСОК ВИКОРИСТАНИХ ДЖЕРЕЛ}

1. Families in Business for the long term. - Mode of access : http://www.europeanfamilybusinesses.eu/. - Title from the screen.

2. Лігоненко Л. Приватний та сімейний бізнес: ситуація у світі та українські реалії / Л. Лігоненко, Г. Піратовський // Торгівля і ринок України / Донецький національний університет економіки і торгівлі ім. М. Туган-Барановського. - 2013. - Вип. 36. - С. 230242.

3. Johanson, J. The Uppsala internationalization process model revisited: From liability of foreignness to liability of outsidership/ J. Johanson, J-E. Vahlne // Journal of International Business Studies. - 2009. - Vol. 40. - P. 1-21.

4. Thomas, J. Determinants of the internationalization pathways of family firms: An Examination of Family Influence / J. Thomas, C. Graves // Family Business Review, - 2008. - Vol. 21 (2) - P. 151-167.

5. Astrachan C. B. Family Business Branding. Leveraging stakeholder trust / C. B. Astrachan, J. H. Astrachan. - London: IFB Research Foundation, 2015. - 46 p.

6. Pinho, J-C. The impact of ownership: Location Specific advantages and managerial characteristics on SME foreign entry mode choices / J-C. Pinho // International Marketing Review. - 2007. - Vol. 24 (6). - P. 715-734.

7. Claver, E. The internationalisation process in family firms: choice of market entry strategies / E. Claver, L. Rienda, D. Quer // Journal of General Management. - 2007. - Vol. 33 (1). - P. 1-14.

8. Офіційний сайт компанії Red Head. [Електронний ресурс]. - Режим доступу: http://redhead.ua/

9. Офіційний сайт компанії GST. [Електронний ресурс]. - Режим доступу: https://www.plomba.net/main/o-kompanii/

10. Офіційний сайт компанії ESKADA M. [Електронний ресурс]. - Режим доступу: http://eskada-m.com/ 